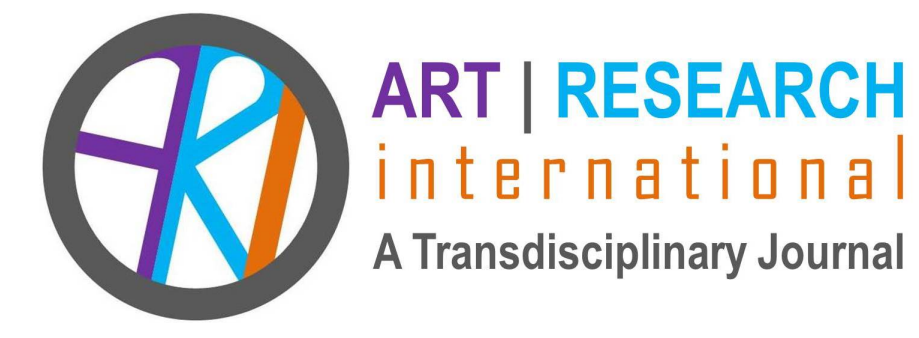

\title{
A REVIEW OF SUSAN CASEY WALSH'S "CONTEMPLATIVE AND ARTFUL OPENINGS: RESEARCHING WOMEN AND TEACHING"
}

\section{Alison Lizette Black University of the Sunshine Coast ablack1@usc.edu.au}

Ali Black is Senior Lecturer, arts-based and narrative researcher at the University of the Sunshine Coast in Queensland, Australia. Ali is interested in autoethnographic, storied and visual approaches for supporting meaning-making, and the power and impact of collaborative and relational knowledge construction. She is working to create a kinder academy and is focused on spaces for female academics to share their experiences.

Abstract: These poetic and visual offerings are responses to Susan Walsh's book Contemplative and Artful Openings. Her book offers to readers an invitation to join the open, emergent space of her text, to wonder and engage. And so, with this review, I have begun.

Keywords: Poetic response; research artifacts; Miksang; awarenessing; (re)imagining 
Are you wanting a different way of being in academia? Tired of the neoliberal machinations and limiting beliefs that see us competing, isolated, anxious and stressed? Do you long for kindness and compassion in the academy, research that makes a difference?

Susan Casey Walsh writes that her "deepest aspiration for Contemplative and Artful Openings is that it be of benefit to others, that it contributes to conversations about research and living well together" (p. xvi). As a reader and a seeker, Susan has caused me to think deeply about what it might mean to "live well together" and to "be differently" in relation to inquiry, to research, to others. From the first to the last page, she has connected me to ongoing moments of "awarenessing" (p. 25).

Contemplative and Artful Openings is a reminder of what matters, it is sustenance for the heart, body, soul and mind. In this honest and vulnerable mosaic of stories, poetic fragments, research questions, and imagery, Susan encourages us to take up Elliot Eisner's call to "see things in fresh ways" (cited in Saks, 1996, p. 412) and recognise the transformational power of creative processes for (re)visiting scholarly ideas, dilemmas, longings, and uneasiness. Scattering examples and stories like landmarks, she describes her own journey across the six chapters, inviting us to explore how contemplative and artful practices might move us closer to an ethic of care and caring, to respectful and compassionate research.

Contemplative and Artful Openings is a resource for anyone wanting to (re)imagine an academy that is kinder, more mindful and care-full. It offers a range of invitations to connect with-in-ourselves-each-other, to become more aware, more conscious of our interactions and intra-actions. Some of these invitations are practical, offering tools and ways to make and find meaning: drawing, creative writing, journaling, poetry, contemplative photography, clustering, art-making, meditation, movement, being with the breath. Invitations are also ontological and philosophical: linked to ways of knowing and feeling, to respect, compassion, equality, to Buddhist ideas, ancient wisdom and spiritual traditions. They are theoretical: feminist and poststructural, acknowledging socio-historical, cultural and political contexts, and female subjects, voices, words and bodies. And they are human - linked to stories of the heart, stories of suffering, fear, violence, uncertainty, injustice and distress. Overarching themes of love and care permeate the artefact-filled pages connecting us to hope, curiosity and relationship. Her weaving of words and imagery are an energetic interplay of thought, language, space, senses, perception, tuning in, and turning outward. Across this work, so many ways to engage with-in-\&-with-the-world-with-other-sentientbeings arise. 
Flowers chopped off headless

the pain of academic life

the weight of deadlines-myriad meetings-committees-expectations demands less attentive than I desire through research teaching and everyday life it is a safety

net but it's a prison too

this book maps a movement from fear to something gentler and more

spacious

textual moves

play with language contemplations poetry,

photography musings

an un-fold-ing process of awareness and awarenessing

artful and contemplative processes forms that

help me go deeper e x $p$ a $n$ d outward

I am a co-creator

of this world

What does this mean for the research process?

\section{Poetic response 1 by Ali Black: Experimenting with found/read words, ideas and spaces}

As a reader interested in arts-based methods, creativity, living well and counting differently, I devoted several restorative days to being with Susan's ideas-writing-invitations. I sat with her words, the images, the felt sense, and I sought to honour and hold space for her offerings, and then to respond - to make connections and open to the sensations. It truly took me on a journey of noticing, of contemplating the ways I know, being with who I am, moving beyond myself. It caused me to explore slowly, heartfully, with fresh eyes. I didn't read it in one sitting. I stopped and engaged in note taking, in writing

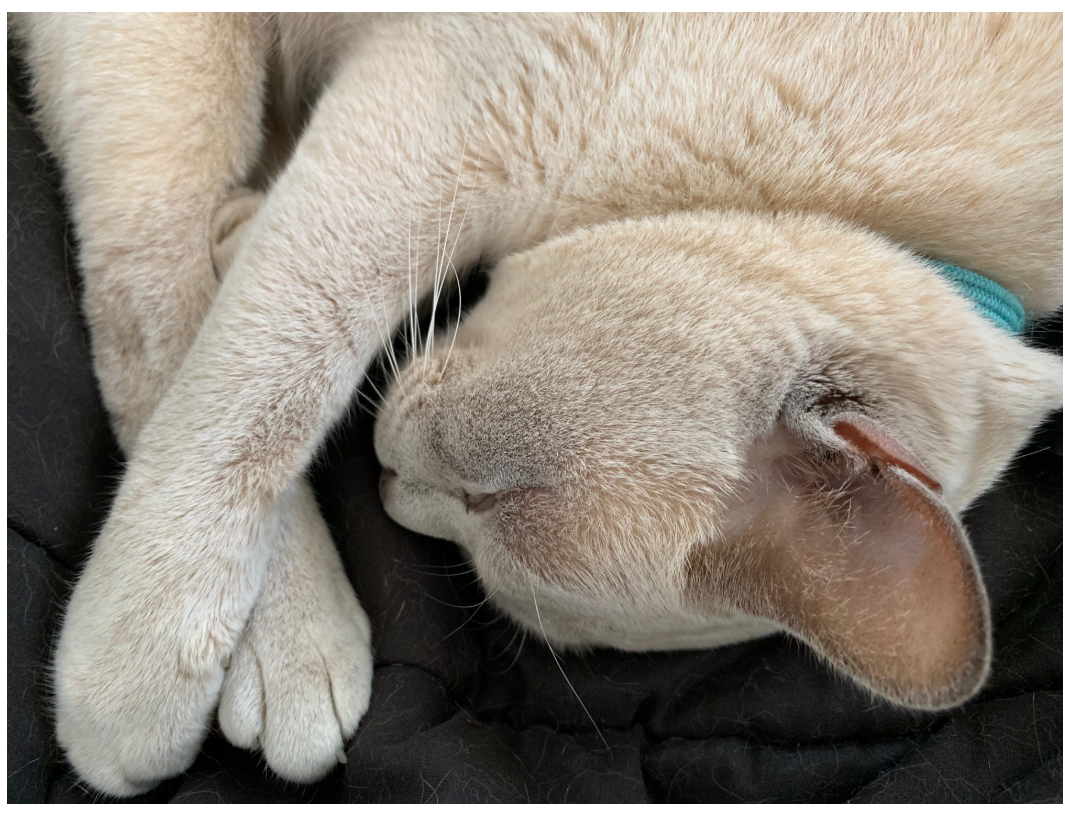

Figure 1. Practicing Miksang, celebrating rest, love, connection and relational space. Photo credit: Ali Black 
my own poetry, in searching the internet to find out more about Miksang (contemplative photography). I gave time to practicing Miksang, celebrating my cat and his whiskers, and the joy of rest. I allowed my eyes to close in meditation, allowed myself to fall into an afternoon nap. My cat and I. Communing. Relational beings.

This book has aroused a sense of spaciousness, through its language, its invitations, its message. Before I began my day of working I walked the beach. I wanted to relate to the earth, to create space in my overworking habits. I touched the earth gently, revelled in the emptiness, the happy dogs, the warming sun, the crashing waves of turquoise and green, the eagle in the blue-grey overhead. I gave time to stillness. Sitting in stillness. Attending to my breath. Noticing. Being-with-in my body and listening more openly. I gave time to my body's sensations, to experiencing each of my senses. I stayed in the moment. Open. Listening to the space around my thoughts, letting them go, inhale and exhale, ebb and flow. "Awarenessing space" (p. 61).

As I walked the beach on a new day something had shifted. I was more alert to the beauty of the world around me. That day, I saw the beauty and I let it in, playfully, somehow more connected to my environment, to the open space. The other day as I was reading Susan's book, I recognised that I simply go too fast, too fast to be with what is, too fast to

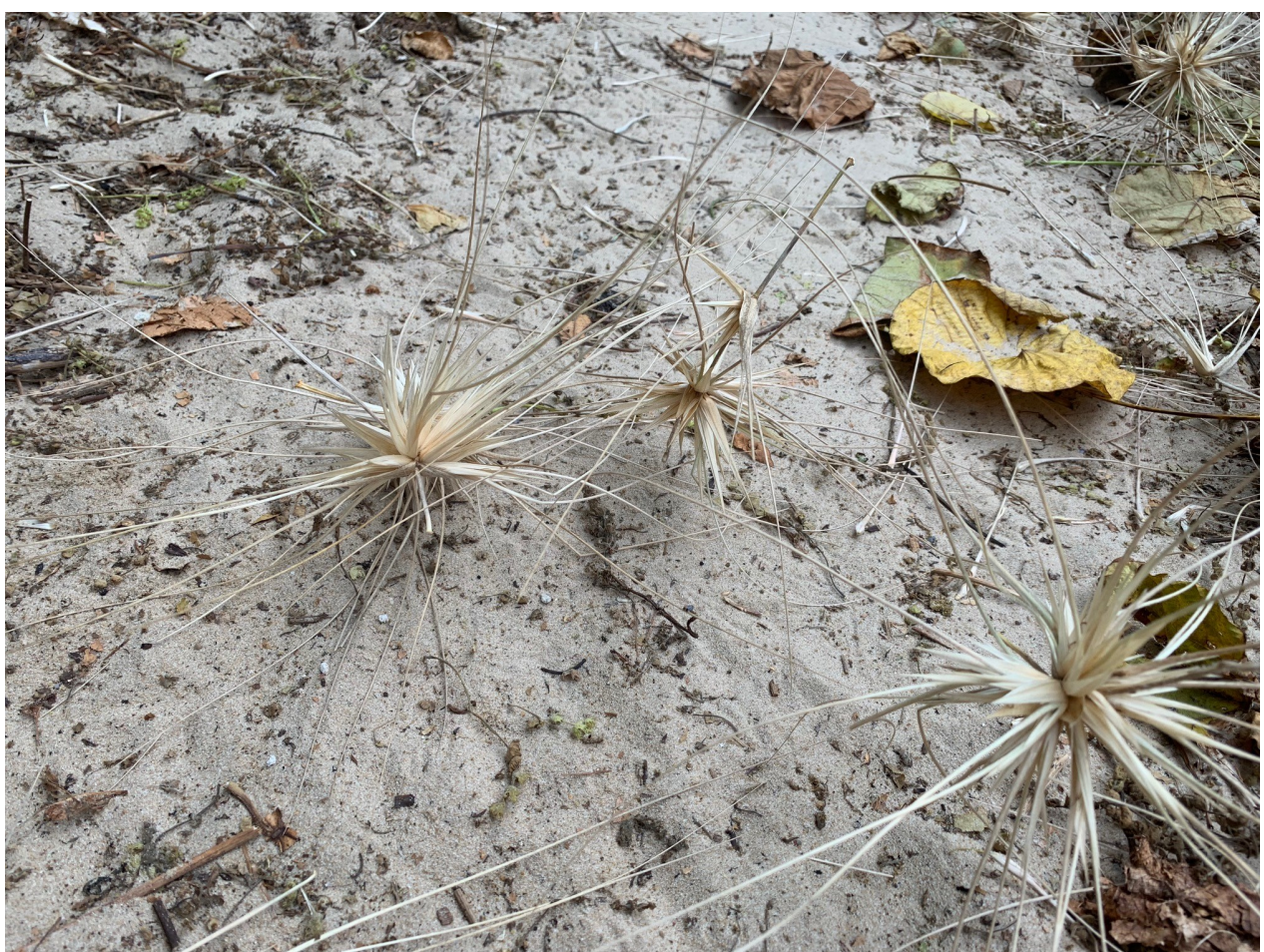

Figure 2. Practicing Miksang, witnessing tumbleweeds: movement, shifting and letting go. Photo credit: Ali Black. notice and observe. I blame it on the relentless demands of my work, the never-ending tasks, but now I am more mindful, I know that I co-create. I recognise that I fill my mind with thoughts, with replays of conversations said and unsaid. I am too caught up with thoughts in my head that I barely touch the world around me, constantly distracted. I realise that I long for space and spaciousness. Where I notice. Where I am still. Where I look with awake eyes and an awake heart. 
this book is a gift, a collection of text and imagery

I feel myself-heart-mind opening as

it invites

spacious ways of being sensing thinking responding as

it invites

my contribution reflection pondering stories ideas awareness

My engagement in a process that exceeds this text, these readings, these writings.

What do I need to learn from this that can help me today?

Engage in processes that make more room

the tumbleweeds greet me and remind me to let go go with the flow and relax notice

allow something new

to emerge

to manifest to fall

away

they call me to play

and explore and wonder and bring

my whole self

I walk the beach senses keener the eagle swirling above me my heart

swells

with joy

the waves over my feet the air

on my skin and in my hair

attuning to the more than human world the energy the beauty the shifting my toes in the sand

remembering the purple flowers and the red beating of your heart and the yellow

clay and the orange clay too

remembering the value of feeling the clay holding

it very care-fully softening

noticing the space around me softening

you have shifted my attention listening

breathing being bearing witness

aware of

my own red beating heart

commingling of inside and outside red blue-grey yellow turquoise orange green purple 


recognising how we
might all live togethermore gently and see ourselves
in the other
thank you Susan

Poetic response 2 by Ali Black: responding poetically, describing feelings, awareness, spaces found

Contemplative and Artful Openings is totally unique. It calls to our essence as humans and as researchers; it calls and connects through its vulnerable and stunning writing, through its heartlines of kindness and compassion. For arts-based researchers it shows what thoughtful methodologies can look like. For contemplative practitioners it highlights how interconnectedness can be fostered and supported. For anyone in the academy it shows research and writing as compassionate contemplative practice, as a way to transform ourselves, our academy and our communities. It is a most beautiful offering that will call you to respond, to imagine, to hope, and to "be" differently. 


\section{REFERENCES}

Saks, A. L. (1996). Should novels count as dissertations in education? Research in the Teaching of English, 30(4), 403-427.

Walsh, S. C. (2017). Contemplative and artful openings: Researching women and teaching. New York, NY: Routledge. 